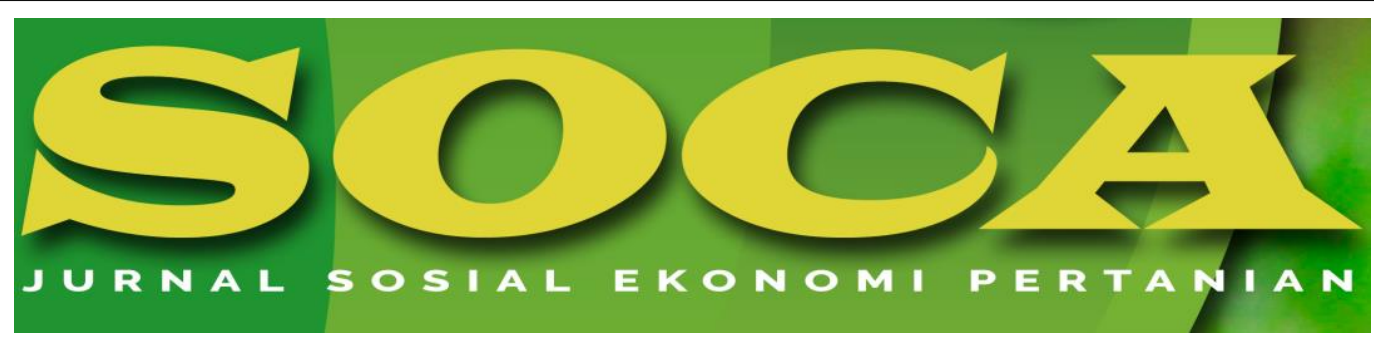

https://ojs.unud.ac.id/index.php/soca

\title{
Production Factors Efficiency Of Potato Farming In Tosari Village
}

Titik Wahyuningsih, Agnes Quartina Pudjiastutiand Sumarno

Tribhuwana Tunggadewi University, Malang, Jawa Timur

E-mail: wahyuningsih.titik@yahoo.co.id, agnespudjiastuti@yahoo.com,

sumarno_mr@yahoo.com

Mobile: 085230366339, 081555761529, 08123242628

Submitted: February 9th, 2020; Revised: March 19th, 2020; Accepted: April 26th 2020

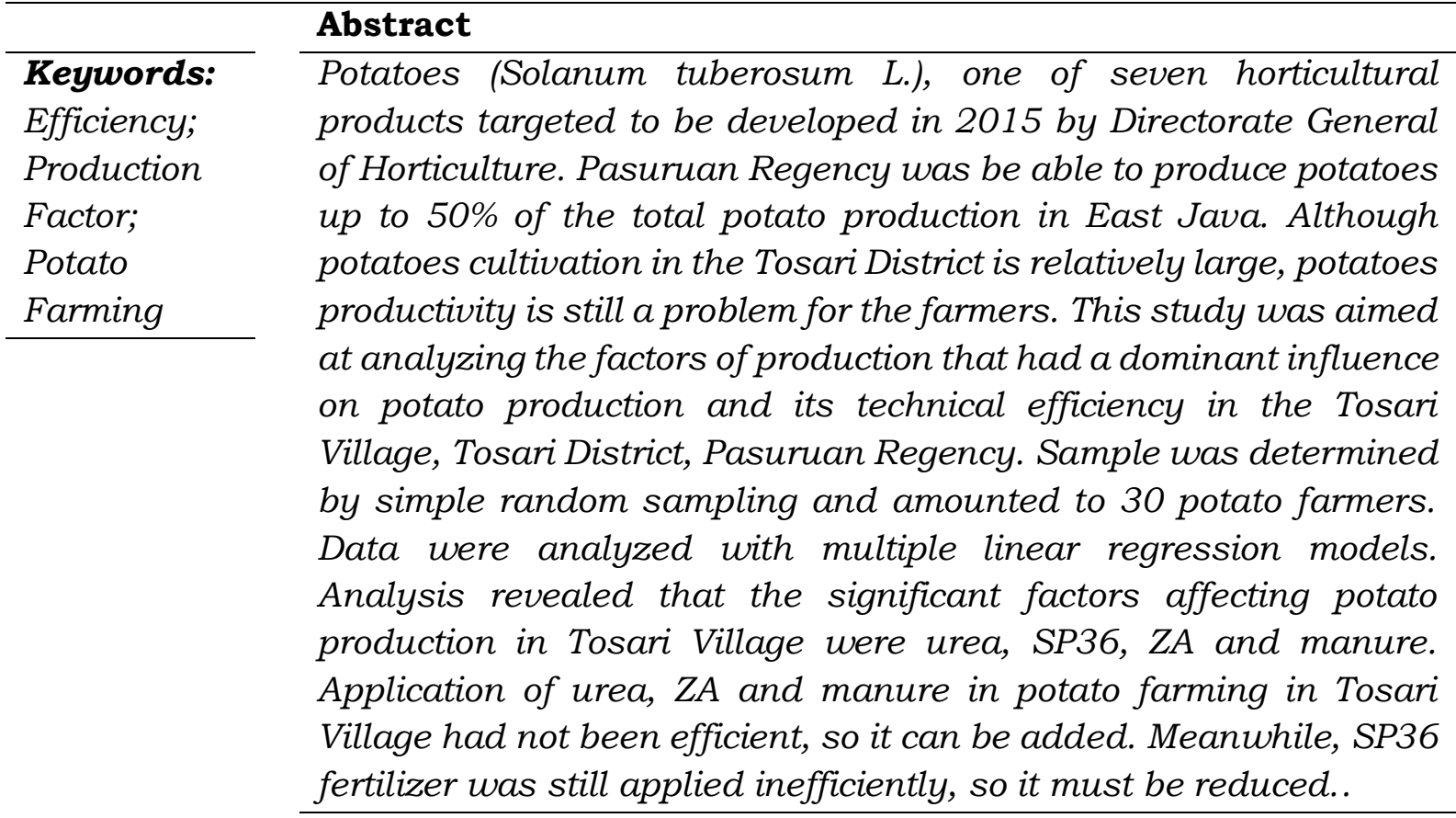

How to Cite (APA 6th Style):

Wahyuningsih, T., Pudjiastuti, A. Q., \& Sumarno. (2020). Production Factors Efficiency Of Potato Farming In Tosari Village. SOCA: Jurnal Sosial Ekonomi Pertanian, 14(3), 511-520.

https://doi.org/https://doi.org/10.24843/SOCA.2020.v14.i03.p12 


\section{INTRODUCTION}

The sector in Indonesia that is currently being developed is horticulture, because it has an important role in agricultural development. Horticultural commodities are grouped into vegetables, fruits, medicinal plants, and ornamental plants (Kementan, 2015).

Potatoes (Solanum tuberosum L.) are the main horticultural commodities targeted for development in the 2015-2019 period by the Ministry of Agriculture (Dirjenhorti, 2015). It is intended to achieve self-sufficiency of potatoes that are planned to be achieved in 2020. Director General of Horticulture also stipulates increase in production and added value of potatoes as one of the strategic targets. Indonesian potato production is still low, due to inadequate soil requirements for potato plants, low available nutrients, emergence of various pests and diseases, provision of fertilizer that is not proportional, use of anorganic fertilizers in very large doses, and incompatibility of potato cultivation.

Potatoes have been cultivated in almost all islands in Indonesia. Although not the largest contributor to potato production nationally, East Java is capable of producing large quantities of potatoes (BPS, 2018). Some research results show the fact that allocation of inputs in potato farming in Indonesia is still inefficient. Thus, production of these commodities can still be increased in order to meet consumer demand.

Development of the processing industry of potato products has increased the demand for potatoes as raw material. Therefore production must also be increased in order to be able to meet these demands. High demand for processed potatoes (potato chips, frozen potatoes, etc.) as a result of the modern lifestyle forced the government to import potatoes. However (Pudjiastuti et al., 2013), (Pudjiastuti, 2014), (Pudjiastuti \& Kembauw, 2018), reminded that increasing imports in the long run will disrupt Indonesian economy.

BPS (2018) states that, the potato imports in 2017 for industrial consumers were 51,849 tons and the value was IDR 275 billion. In 2018, this import will decrease significantly to 29,649 tons, or valued at IDR 117 billion. It was indicated that potato imports value by industry dropped significantly (> 50\%). So, increasing yield of domestic potatoes is a very important to reduce dependence on imported potatoes. It will be more effective if it is focused on potato center through efficiency of its production factors.

There are several potato centers in East Java, including Tosari District, Pasuruan Regency. The region has been able to produce potatoes up to $50 \%$ of the total production in East Java (BPS, 2018). Geographical location $(1,700 \mathrm{~m}$ asl) and temperature (minimum 180-200 ${ }^{\circ} \mathrm{C}$ ) suitable for potato cultivation are the main capital for local farmers. Although cultivation of potatoes in Tosari District is quite large, their productivity is still a problem for farmers.

Table 1. Potato Productivity in Pasuruan Regency

\begin{tabular}{cccc}
\hline Year & Land Area (ha) & Yield (ton) & Productivity (ton/ha) \\
\hline 2013 & 3.049 & 64.934 & 21,30 \\
2014 & 3.318 & 88.384 & 26,64 \\
2015 & 3.227 & 90.459 & 28,03 \\
2016 & 3.634 & 97.483 & 26,83 \\
2017 & 4.013 & 110.825 & 27,62 \\
\hline
\end{tabular}

Source: Kabupaten Pasuruan Dalam Angka, 2019 
Potato productivity in Pasuruan Regency tends to increase from 2013-2017, but this figure is still relatively low when compared to national scale productivity. There are many factors that determine potato production, namely land area, chemical fertilizer, and organic fertilizer (Agatha \& Wulandari, 2018); land area, seeds and pesticides (Fianda et al., 2016), labor and capital (Mawardati, 2013) and land area (Pratiwi \& Hardyastuti, 2018). On the other hand, (Maryanto et al., 2018), (Widayati, 2017), (Rizkiyah et al., 2014) and (Hartati \& Setyadji, 2012) stated that potato farming has not been efficient. According to (Sa'diyah \& Pudjiastuti, 2017), potato production depends on the allocation of seeds number, land area, artificial fertilizer, manure, labor, and pesticides. Potato farming was also profitable with R/C > 1 (Herliani et al., 2019). This study selects several factors that affect potato farming in Tosari Village based on several previous research results. However, fertilizer variable is based on the type applied by potato farmers in the study location, namely urea, SP36, $\mathrm{ZA}, \mathrm{KCl}$, and manure.

This research was intended to analyze: 1) factors that affect potato production and 2) efficiency of production factors in potato farming in Tosari Village, Tosari District, Pasuruan Regency.

\section{RESEARCH METHODS}

This research was conducted in Tosari Village, Tosari District, Pasuruan Regency. Pasuruan Regency was determined purposively because it is a center for producing potatoes in East Java. Tosari District was chosen purposively because it is a center of potatoes in Pasuruan Regency and even the largest in East Java Province. Pasuruan Regency contributes to $60 \%$ of the province's potato needs.

Population was defined as all Tosari Village farmers who planted granola flower varieties of potatoes, amounting to 62 people. Sample was determined by simple random sampling. According to (Sugiyono, 2019), this method is the process of selecting respondents where each member of population has an equal chance of being elected. Potato farmers generally have a relatively homogeneous land area. Samples number were set at 30 farmers (50\% of total population).

Data collected were primary and secondary data. Primary data were collected through interviews using a questionnaire, including: characteristics of farmers such as age, experience, education, number of family members, intensity of attending counseling and production data, potato prices, input prices and use of inputs. Inputs intended: seeds, land, fertilizers by type (urea, SP36, KCl, ZA, manure), pesticides, and labor. Secondary data is data that had been collected, sorted and documented by second parties. These parties are Central Statistics Agency (BPS), Ministry of Agriculture of Indonesia Republic, Department of Agriculture, Village Office. Data collected includes supporting information on primary data such as a general description of the study area, population and so on.

Regression models were used to analyze the effect of seed use, land area, urea fertilizer, SP36 fertilizer, KCL fertilizer, ZA fertilizer, manure, pesticides and labor on potato production both simultaneously and partially. The regression model used is (Sugiyono, 2011):

$$
Y=a+b_{1} X_{1}+b_{2} X_{2}+b_{3} X_{3}+b_{4} X_{4}+b_{5} X_{5}+b_{6} X_{6}+b_{7} X_{7}+b_{8} X_{8}+b_{9} X_{9}
$$


Where, Y: potato production, a: constant, b: regression coefficient, $\mathrm{X} 1$ : seed use, X2: land area, X3: use of urea fertilizer, X4: use of fertilizer SP36, X5: use of KCL fertilizer, X6: use of fertilizer ZA , X7: use of manure, X8: use of pesticides and X9: use of labor.

Determination coefficient becomes a basis for measuring goodness of fit the multiple linear regression model. The values range of it is from 0 to 1 (Ghozali, 2012). The closer it is to one, the coefficient will show a better regression model.

$\mathrm{F}$ test is a verification procedure whether seed, land area, urea fertilizer, SP36, $\mathrm{KCl}$, $\mathrm{ZA}$, manure, pesticides and labor have a significant effect simultaneously on the yield of potato production. According to (Ghozali, 2012), if the significance probability is $<0.05$, then there is a simultaneous real effect of these variables on potato production. Then, it is continued by t-test to find out which variables that influence individually.

The next step was to measure inputs efficiency in potato farming. Allocative efficiency (or price efficiency) will be achieved if the marginal product value (NPMx) is equal to the intended input price (Px). This condition is expressed mathematically as:

$$
\mathrm{NPMx}=\mathrm{Px} \text { or } \boldsymbol{N P M x} / \boldsymbol{P x}=1 . \boldsymbol{b Y} \cdot \boldsymbol{P} \boldsymbol{x} / \boldsymbol{x}=\boldsymbol{P} \boldsymbol{x} \text { or } \boldsymbol{b Y} . \boldsymbol{P} \boldsymbol{x} / \boldsymbol{X} . \boldsymbol{P} \boldsymbol{x}
$$

Where: $\mathrm{b}=$ elasticity, $\mathrm{Y}=$ production, $\mathrm{Py}=$ price of goods $\mathrm{Y}, \mathrm{X}=$ number of production factors $\mathrm{X}, \mathrm{Px}=$ price of production factors $\mathrm{X}$. If $\mathrm{NPMx} / \mathrm{Px}>1$, then input $\mathrm{x}$ application is not efficient and must be increased. If $\mathrm{NPMx} / \mathrm{Px}<1$, then application of input $\mathrm{x}$ is inefficient and must be reduced. Price efficiency can be achieved if NPMx/Px $=1$.

\section{RESULTS AND DISCUSSION Farmer Characteristics}

Socio-economic characteristics of farmers in Tosari Village, Tosari District, Pasuruan Regency were observed: age, level of education, farming experience and family members. Farmers distribution according to their characteristics is presented in Table 2.

Most (86.7\%) farmers in Tosari Village are in the 30-50 years age category, while the rest (13.3\%) farmers are over 51 years old. Age of farmers will determine the pattern of decision making in using production technology, especially those that can increase production. They will be easier to accept innovation for farming development. Most $(66.7 \%)$ farmers in Tosari Village only had elementary to junior high school education, while the rest (33.3\%) had high school education. The fact is that potato farming does not require a high education. So anyone can participate in this farm. Most (60\%) farmers in the village of Tosari have been doing potato farming in a period of 6-11 years, so it can be said that farmers in this region have a lot of experience in the cultivation of potato plants. These characteristics are important for decision makers in implementing potato commodity development policies in Tosari Village. The parties concerned with the development of potato crops (both private and government) will be easier to direct farmers who have relatively long experience in potato farming. Most (93.3\%) farmers in Tosari Village have dependents of 3-5 people. More and more family members, farmers will try to increase farm income to meet the needs of his family. 
Table 2. Farmer Characteristics

\begin{tabular}{lccc}
\hline \multicolumn{1}{c}{ Variable } & Category & Frequency & $\begin{array}{c}\text { Percentage } \\
\text { (\%) }\end{array}$ \\
\hline \multirow{4}{*}{ Age (year) } & $30-40$ & 14 & 46,7 \\
& $41-50$ & 12 & 40,0 \\
& $>51$ & 4 & 13,3 \\
\hline \multirow{4}{*}{ Education } & Total & 30 & 100 \\
\cline { 2 - 4 } & Elementary School & 8 & 26,7 \\
& Middle School & 12 & 40,0 \\
& High School & 10 & 33,3 \\
\cline { 2 - 4 } Farming experience (year) & Total & 30 & 100 \\
\cline { 2 - 4 } & $1-5$ & 4 & 13,3 \\
& $6-10$ & 14 & 46,7 \\
\cline { 2 - 4 } & $>11$ & 12 & 40,0 \\
\hline \multirow{3}{*}{ Family members (person) } & Total & 30 & 100 \\
\cline { 2 - 4 } & $1-2$ & 2 & 6,7 \\
\cline { 2 - 4 } & $3-4$ & 6 & 73,3 \\
& $>5$ & 30 & 100 \\
\hline
\end{tabular}

Source: Primary Data 2019, processed.

\section{Effect of Production Factor Allocation on Potato Production}

Regression models to analyze the effect of seed usage $\left(\mathrm{X}_{1}\right)$, land area $\left(\mathrm{X}_{2}\right)$, urea fertilizer $\left(X_{3}\right)$, SP36 fertilizer $\left(X_{4}\right)$, KCL fertilizer $\left(X_{5}\right)$, ZA fertilizer $\left(X_{6}\right)$, manure $\left(X_{7}\right)$, pesticide use $\left(\mathrm{X}_{8}\right)$ and labor $\left(\mathrm{X}_{9}\right)$ on the production of potato farming $(\mathrm{Y})$. Based on the multiple linear regression analysis, the effect of seeds usage, land area, urea fertilizer, SP36 fertilizer, KCL fertilizer, ZA fertilizer, manure, pesticides and labor on production of potato farming, were presented in Table 3.

Coefficient of determination $\left(\mathrm{R}^{2}\right)=0.799$ shows that $79.9 \%$ of variation in potato production could be explained by variations in the use of seeds, land area, urea fertilizer, SP36 fertilizer, KCL fertilizer, ZA fertilizer, manure, pesticides and labor, the remaining $(20.1 \%)$ was explained by other variables.

$F$ test with sig. $F=0,000$ indicates that the use of seeds, land area, urea fertilizer, SP36 fertilizer, KCL fertilizer, ZA fertilizer, manure, pesticides and labor simultaneously had a significant effect on the production of potato farming. These results serve as a guideline that $t$ test needs to be done to show which production factors had significant effect on potato production, which is the basis of efficiency analysis. In detail, the partial test results are presented in Table 3.

Table 3. Summary of Regression Test Partially

\begin{tabular}{|c|c|c|c|c|c|}
\hline \multirow[b]{2}{*}{ Variable/parameter } & \multicolumn{2}{|c|}{ Unstandardized Coefficients } & \multirow[b]{2}{*}{$\mathbf{t}$} & \multirow[b]{2}{*}{ Sig. } & \multirow[b]{2}{*}{ Justification } \\
\hline & B & $\begin{array}{c}\text { Standard } \\
\text { Error }\end{array}$ & & & \\
\hline Constant (a) & 803,203 & 210,782 & 3,811 & 0,001 & - \\
\hline Seeds $\left(X_{1}\right)$ & 0,037 & 0,130 & 0,285 & 0,778 & not significant \\
\hline Land area $\left(\mathrm{X}_{2}\right)$ & $-41,011$ & 129,512 & $-0,317$ & 0,755 & not significant \\
\hline Urea fertilizer $\left(X_{3}\right)$ & $4,176^{*}$ & 0,548 & 7,616 & 0,000 & significant \\
\hline SP36 fertilizer $\left(\mathrm{X}_{4}\right)$ & $-11,475^{*}$ & 1,275 & $-8,998$ & 0,000 & significant \\
\hline $\mathrm{KCl}$ fertilizer $\left(\mathrm{X}_{5}\right)$ & 0,869 & 0,857 & 1,015 & 0,322 & not significant \\
\hline
\end{tabular}




\begin{tabular}{lccccc} 
ZA fertilizer $\left(\mathrm{X}_{6}\right)$ & $18,511^{*}$ & 0,726 & 25,495 & 0,000 & significant \\
Manure $\left(\mathrm{X}_{7}\right)$ & $0,560^{*}$ & 0,033 & 16,758 & 0,000 & significant \\
Pesticide $\left(\mathrm{X}_{8}\right)$ & $-57,685$ & 59,261 & $-0,973$ & 0,342 & not significant \\
Labor $\left(\mathrm{X}_{9}\right)$ & 2,664 & 5,576 & 0,478 & 0,638 & not significant \\
\hline $\mathrm{R}^{2} \quad: 0,799$ & & & & \\
F Statistic $: 977,132$ & & & & \\
Sig. F $: 0,000$ & & & & \\
Dependen variable : Potato production (Y) & & & & \\
\hline
\end{tabular}

Source: Primary Data 2019, processed.

Based on Table 3, potato production function in Tosari Village can be written mathematically:

$$
\begin{gathered}
Y=803,203+0,037 X_{1}-41,011 X_{2}+4,176 X_{3}-11,475 X_{4}+0,869 X_{5}+18,511 X_{6} \\
+0,560 X_{7}-57,685 X_{8}+2,664 X_{9}
\end{gathered}
$$

where the use of urea fertilizer, SP36 fertilizer, ZA fertilizer and manure have a significant effect on potato production.

The $t$ test showed that urea fertilizer, SP36 fertilizer, ZA fertilizer and manure had a significant effect on potato production. The results of this analysis are in accordance with the findings (Agatha \& Wulandari, 2018) although only mentioning chemical fertilizers and organic fertilizers, but different from the findings (Mawardati, 2013), (Pratiwi \& Hardyastuti, 2018) and (Fianda et al., 2016) that fertilizers has no influence on potato production and income. The effect of production factors on potato production is explained in detail below.

1. Constant (a)

Constant as a result of regression analysis is 803,203 . It shows that without changes in seed, land area, urea fertilizer, SP36 fertilizer, KCL fertilizer, ZA fertilizer, manure, pesticides and labor, the potato production obtained was $803,203 \mathrm{~kg} / \mathrm{ha}$.

2. Seeds $\left(X_{1}\right)$

Regression coefficient of seed use $=0.037$. It shows that an increase one kilogram of seeds in potato farming, production of potatoes will increase by $0.308 \mathrm{~kg}$, if variable land area, urea fertilizer, SP36 fertilizer, KCL fertilizer, ZA fertilizer, manure, pesticides and labor were assumed to be constant.

3. Land area $\left(\mathrm{X}_{2}\right)$

Regression coefficient of this variable in potato farming was $-41,011$. It shows that an increase of one hektare of land planted with potatoes will reduce potato production by $41,001 \mathrm{~kg}$, if variables such as seed use, urea fertilizer, SP36 fertilizer, KCL fertilizer, ZA fertilizer, manure, pesticides and labor were assumed to be constant.

4. Urea fertilizer $\left(\mathrm{X}_{3}\right)$

Regression coefficient of urea fertilizer was 4.176. It is mean that, an increase one kilogram of urea fertilizer in potato farming, then potato production will increase by $4.176 \mathrm{~kg}$, if variable use of seeds, land area, SP36 fertilizer, KCL fertilizer, ZA fertilizer, manure, pesticides and labor were assumed to be constant. 
5. SP36 fertilizer $\left(\mathrm{X}_{4}\right)$

SP36 fertilizer regression coefficient was obtained for $-11,475$. It is mean that, every increase in the use of SP36 by one kilogram in potato farming will reduce production of potatoes by $11,475 \mathrm{~kg}$, if variable use of seeds, land area, urea fertilizer, KCL fertilizer, ZA fertilizer, manure, pesticides and labor were assumed to be constant.

6. KCL fertilizer $\left(\mathrm{X}_{5}\right)$

Regression coefficient of KCL fertilizer calculation results is 0.869 . It is mean that, each increase one kilogram of KCL fertilizer in potato farming, it will increase potato production by $0.869 \mathrm{~kg}$, if variable use of seeds, land area, urea fertilizer, SP36 fertilizer, ZA fertilizer, manure, pesticides and labor were assumed to be constant.

7. Pupuk ZA $\left(\mathrm{X}_{6}\right)$

ZA fertilizer regression coefficient obtained for 18.511. It is mean that, every one kilogram increase in the use of ZA fertilizer in potato farming, it will increase production of potatoes by $18,511 \mathrm{~kg}$, if variable use of seeds, land area, urea fertilizer, SP36 fertilizer, KCL fertilizer, manure, pesticides and labor were assumed to be constant.

8. Manure $\left(\mathrm{X}_{7}\right)$

Regression coefficient of manure is 0.560 . That is, every one kilogram increase in the use of manure in potato farming, production of potatoes will increase by 0.560 $\mathrm{kg}$, if variable use of seeds, land area, urea fertilizer, SP36 fertilizer, KCL fertilizer, ZA fertilizer, pesticides and labor were assumed to be constant.

9. Pesticides $\left(\mathrm{X}_{8}\right)$

Regression coefficient of the use of pesticides in potato farming is $-57,685$. That is, every one kilogram increase of pesticides in potato farming, it will reduce production of potatoes by $57,685 \mathrm{~kg}$, if variable use of seeds, land area, urea fertilizer, SP36 fertilizer, KCL fertilizer, ZA fertilizer, manure and labor were assumed to be constant.

10. Labor $\left(\mathrm{X}_{9}\right)$

Regression coefficient of labor use in potato farming was obtained at 2.664. That is, each increase of one man working day ( $\mathrm{HOK}=$ hari orang kerja) in potato farming, it will increase production of potato farming by $2,664 \mathrm{~kg}$, if variable use of seeds, land area, urea fertilizer, SP36 fertilizer, KCL fertilizer, ZA fertilizer, manure and pesticides were assumed to be constant.

\section{Efficiency of Potato Production Factors}

Allocative efficiency of potato production factors that have a significant influence on potato production in Tosari Village: urea fertilizer, SP36 fertilizer, ZA fertilizer and manure, can be seen in Table 4.

NPMxi/Pxi urea fertilizer usage of 36.36 shows that application of urea fertilizer was not yet efficient. NPMxi/Pxi > 1, indicates the need for addition of urea fertilizer in potato farming, if farmers want to achieve conditions of efficient use of urea fertilizer.

NPMxi/Pxi for SP36 fertilizer was -99.92, indicating that the use of SP36 fertilizer was not efficient. NPMxi/Pxi $<1$ indicates the need to reduce SP36 fertilizer in potato farming, if farmers want to achieve efficiency conditions of SP36 fertilizer. 
NPMxi/Pxi for ZA fertilizer was 161.18, proving that the use of ZA fertilizer was still not yet efficient. NPMxi/Pxi > 1, indicates the need for addition of ZA fertilizer in potato farming, if farmers want to achieve efficiency conditions of ZA fertilizer usage.

Table 4. Efficiency of Potato Farm Production Factors

\begin{tabular}{cccccccc}
\hline Variable & $\mathbf{B i}$ & $\mathbf{P y}$ & $\mathbf{X i}$ & $\mathbf{P x i}$ & $\mathbf{N P M x i}$ & NPMxi/Pxi & Efficiency \\
\hline Urea fertilizer & 4,176 & 8.000 & 183 & 2.100 & $76.361,14$ & 36,36 & Not yet \\
SP36 fertilizer & $-11,475$ & 8.000 & 200 & 2.100 & $-209.828,57$ & $-99,92$ & Not \\
ZA fertilizer & 18,511 & 8.000 & 212 & 2.100 & $338.486,86$ & 161,18 & Not yet \\
$\quad$ Manure & 0,560 & 8.000 & 2750 & 500 & $43.008,00$ & 86,016 & Not yet \\
\hline
\end{tabular}

Source: Primary Data 2019, processed.

NPMxi/Pxi of manure is 86,016 , which is an indicator that the use of manure is still not yet efficient. NPMxi/Pxi > 1 indicates the need to add manure to potato farming can be done, if farmers want to achieve conditions of efficient use of manure.

\section{CONCLUSIONS}

Production factors that had a significant influence on potato production in the Tosari Village were urea fertilizer, SP36 fertilizer, ZA fertilizer and manure with regression coefficients respectively for $4.176,-11.475,18.511$ and 0.560 . The use of production factors in potato farming in Tosari Village has not yet reached efficiency. The results of the efficiency analysis revealed that urea fertilizer, ZA fertilizer and manure applied by farmers were classified as inefficient (with NPMxi/Pxi respectively: 36.36; 161.18; and 86.016), while SP36 fertilizer was classified as not efficient (with NPMxi/Pxi: -99,92).

\section{RECOMMENDATION}

To increase production yields or achieve inputs efficiency of potato farming in Tosari Village, farmers should increase urea fertilizer, ZA fertilizer, and manure, and the other hand, reduce the use of SP36 fertilizer. Application of organic fertilizer (manure) and balanced anorganic fertilizer can be based on the experience of farmers, because farmers better understand the management conditions of potato farming. Future studies can use different regression models, for example, Cobb Douglas production function which may be more suitable for research in agriculture, considering that other production factors have no significant effect. Another alternative is to add variables based on relevant research results.

\section{REFERENCES}

Agatha, M. K., \& Wulandari, E. (2018). Analisis Faktor-Faktor yang Mempengaruhi Produksi Kentang di Kelompok Tani Mitra Sawargi Desa Barusari Kecamatan pasirwangi Kabupaten Garut. Jurnal Ilmiah Mahasiswa Agroinfo Galuh, 4(3), 772-778. https://media.neliti.com/media/publications/276073-analisisfaktor-faktor-yang-mempengaruhi-baf6501c.pdf

BPS. (2018). Kabupaten Pasuruan Dalam Angka. Badan Pusat Statistik.

Dirjenhorti. (2015). Statistik Produksi Hortikultura 2014. Kementerian Pertanian, 
Dirjen Hortikultura.

Fianda, A., Fadli, \& Zuriani. (2016). Analisis Faktor-Faktor yang Mempengaruhi Produksi Kentang di Kecamatan Timang Gajah Kabupaten Bener Meriah. Jurnal Agrifo, 1(1), 42-53.

Ghozali, I. (2012). Aplikasi Analisis Multivariate dengan Program IBM SPSS. Universitas Diponegoro.

Hartati, A., \& Setyadji, K. (2012). Tingkat Efisiensi Faktor Produksi Pada Usahatani Kentang Di Kecamatan Karangreja Kabupaten Purbalingga Jawa Tengah. Agrin, 16(1), 1-30. https://doi.org/10.1017/CBO9781107415324.004

Herliani, D. R., Sumarjono, D., \& Setiawan, B. M. (2019). Analisis Pendapatan Usahatani Monokultur Kentang Dan Tumpangsari Kentang-Carica Desa Sembungan Kecamatan Kejajar Kabupaten Wonosobo. SOCA, 13(3), 291-303. https: / / doi.org/10.24843/SOCA.2019.v13.i03.p01

Kementan. (2015). Rencana Strategis Kementerian Pertanian 2015-2019. Kementerian Pertanian.

Maryanto, M. A., Sukiyono, K., \& Sigit Priyono, B. (2018). Analisis Efisiensi Teknis dan Faktor Penentunya pada Usahatani Kentang (Solanumtuberosum L.) di Kota Pagar Alam, Provinsi Sumatera Selatan. AGRARIS: Journal of Agribusiness and Rural Development Research, 4(1), 1-8. https: / /doi.org/10.18196/agr.4154

Mawardati. (2013). Kentang Di Kabupaten Bener Meriah Provinsi Aceh Analysis of Factors Affecting Potato Farming Income in Bener Meriah District Province of Aceh. Jurnal Agrium, 10(2), 38-42.

Pratiwi, L. F. L., \& Hardyastuti, S. (2018). Analisis Faktor-Faktor Yang Mempengaruhi Pendapatan Usahatani Kentang Pada Lahan Marginal Di Kecamatan Kejajar Kabupaten Wonosobo. Berkala Ilmiah AGRIDEVINA, 7(1), 14-26. https://doi.org/10.33005/adv.v7i1.1127

Pudjiastuti, A. Q. (2014). Perubahan Neraca Perdagangan Indonesia Sebagai Akibat Penghapusan Tarif Impor Gula. Agriekonomika, 3(2), 106-116.

Pudjiastuti, A. Q., Anindita, R., Hanani, N., \& Kaluge, D. (2013). Effects of Sugar Price Increase in Indonesia. Oeconomica, 58(1), 28-39. https://doi.org/http://studiaoeconomica.ubbcluj.ro/volumes.html

Pudjiastuti, A. Q., \& Kembauw, E. (2018). Sugar Price Policy and Indonesia's Trade Balance. Journal of Advanced Research in Law and Economics, 8(8). https://doi.org/10.14505/jarle.v8.8(30).26

Rizkiyah, N., Syafrial, \& Hanani, N. (2014). Faktor-Faktor Yang Mempengaruhi Efisiensi Teknis Usahatani Kentang (Solanum Tuberosum L) Dengan Pendekatan Stochastic Production Frontier (Kasus Desa Sumber Brantas Kecamatan Bumiaji Kota Batu). Habitat, XXV(1), 25-31.

Sa'diyah, A. A., \& Pudjiastuti, A. Q. (2017). Faktor Penentu Produksi Sayuran Daerah Dataran Tinggi Di Kecamatan Sukapura Kabupaten Probolinggo. Agriekonomika, 
https://doi.org/http://dx.doi.org/10.21107/agriekonomika.v6i1.1895

Sugiyono. (2019). Metode Penelitian Kuantitatif, Kualitatif dan R\&D (1st ed.). Alfabeta.

Widayati, T. (2017). Analisis Efisiensi Penggunaan Faktor Produksi Pada Usahatani Kentang Di Kawasan Dieng Jawa Tengah. Prosiding Seminar Nasional \& Call for Papers, 156-161. 